\title{
Data Envelopment Analysis for Container Terminals Considering an Undesirable Output - Focus on Busan Port \& Kwangyang Port
}

\author{
Chang-Hoon Shin*, + Dong-Hun Jeong \\ * Department of Logistics Engineering, Korea Maritime University, Busan 606-791, Republic. of Korea \\ + Graduate School of Logistics System, Korea Maritime University, Busan 606-791, Republic. of Korea
}

\begin{abstract}
Recently according to increase of enlarged scale ports in conformity with increase in over size vessels and container handling service, pollutants generated from ports are increasing. In advanced countries, reduction in carbon dioxide emission assigned to them has been implemented according to the Climate Change Convention and Kyoto Protocol from 2008 to 2012 in order to lessen carbon dioxide emission. Henceforth increase in discussion on the measure of constructing Green Port and low-carbon port is expected in our nation's field of port as well, it is considered that the effort in reduction with regard to undesirable output which causes environmental problem of analysis target during measuring effectiveness. Therefore, in this study, effectiveness was estimated through directional technology distance function considering undesirable output differently from effectiveness analysis of existing container terminal, and then performed comparative analysis with the result analyzed with BCC output-oriented model. As the result of analysis, in 2007 DMU3 and DMU5, and in 2010 DMU2 and DMU4 appeared to be efficient terminals in BCC output oriented model, and in directional technology distance function model, DMU1, DMU3 in 2007, DMU3, DMU5 in 2008, DMU7 in 2009, and DMU2, DMU5 in 2010 appeared to be efficient terminals.
\end{abstract}

Key words : DEA(Data Envelopment Analysis), BCC output oriented model, Undesirable Output, Directional Distance Function, $\mathrm{CO}_{2}$ Emission

\section{Introduction}

\subsection{Background of study}

With growing global economy, economic growth of advanced countries and developing countries are also being progressed remarkably. With economic growth, export import industry, and logistics industry that are base of economic growth are also growing along with. The effort and competition to create container throughput between ports also become pierce as economy is growing. The interest and importance for the efficient measurement of port are being increased. There are many researches being progressed to analyze efficiency of container terminals in relation with efficiency of ports. However, there is no research conducted yet about undesirable outputs generated from port, i.e., pollutants discharges. These issues can be regarded as directly linked with latest global warming.

In this study, we investigated how carbon dioxide (Hereafter $\mathrm{CO}_{2}$ ) associated with energy that can be generated from port affects on the efficiency of port.

\footnotetext{
* chshin@hhu.ac.kr 051)410-4333

† Corresponding author, jaydhoony@hhu.ac.kr 051)410-4930
}

\subsection{Purpose of study}

In this study, pollutant such as green house gas was additionally considered in the existing port efficiency measurement method to differentiate from existing studies (Roll and Hayuth, 1993; Cullinane et al, 2002; Park and Lee, 2007; Jeong, 2009; Cho, 2010; Mo and Lee, 2010).

Also, by using undesirable outputs and Directional Distance Function, it has a meaning of supplementing existing port efficiency studies. We wish the efficiency analysis in this study considering undesirable outputs can boost up global warming studies at current port and logistics scenario.

\section{Theoretical study}

\subsection{Study of DEA about port}

The DEA(Data Envelopment Analysis, Hereafter DEA) researches in relation with ports are as below.

Choi et al. (2009), in their research proposed importance of efficiency analysis considering informationization level for the efficient operation of container terminals, and 
Data Envelopment Analysis for Container Terminals Considering an Undesirable Output

- Focus on Busan port \& Kwangyang port

measured relative efficiency in association with informationization level by using DEA and Bootstrap. When informationization level was considered, they showed that efficiency scores of most of DMU became higher than the cases when only facility was considered as an input variable.

In the study conducted by Park (2010), he asserted that since cargo handling equipments at port terminals are highly expensive, invest is needed in facilities, and cargo handling service is provided at same condition as per terminal operation, for each port there is need to raise efficiency in transshipment throughput by utilizing facilities more systematically and effectively.

Table 1 Summary of Previous Studies about Port Using DEA

\begin{tabular}{|c|c|c|c|c|}
\hline Researcher & Methodology & $\begin{array}{l}\text { Input } \\
\text { Factor }\end{array}$ & $\begin{array}{l}\text { Output } \\
\text { Factor }\end{array}$ & $\begin{array}{l}\text { Target of } \\
\text { Evaluation }\end{array}$ \\
\hline $\begin{array}{c}\text { Choi et al. } \\
(2009)\end{array}$ & $\begin{array}{c}\text { DEA } \\
\text { Bootstrap }\end{array}$ & $\begin{array}{l}\text {-Quay Length } \\
\text { CY Area } \\
\text {-Number of } \\
\text { Crane } \\
\text {-Investment Cost } \\
\text {-Operating } \\
\text { Expenses } \\
\text { - Labor Costs }\end{array}$ & $\begin{array}{l}\text { Total Output } \\
\text { Throughput }\end{array}$ & $\begin{array}{c}\text { Domestic } \\
\text { (8 Terminal) }\end{array}$ \\
\hline $\begin{array}{l}\text { Park } \\
\text { (2010) }\end{array}$ & DEA & $\begin{array}{l}\text { CY Area } \\
\text {-Number of } \mathrm{C} / \mathrm{C} \\
\text { Number of } \mathrm{T} / \mathrm{C} \\
\text { - Number of } \mathrm{Y} / \mathrm{T}\end{array}$ & $\begin{array}{l}\text { Transshipment } \\
\text { Cargo } \\
\text { Throughput }\end{array}$ & $\begin{array}{c}\text { Busan Port } \\
\text { Kwangyang } \\
\text { Port } \\
\text { (11 Terminal) }\end{array}$ \\
\hline
\end{tabular}

Footnote : CY Area(Container Yard Area, Hereafter CY)

$\mathrm{C} / \mathrm{C}($ Container Crane, Hereafter $\mathrm{C} / \mathrm{C})$

$\mathrm{T} / \mathrm{C}($ Transfer Crane, Hereafter $\mathrm{T} / \mathrm{C})$

$\mathrm{Y} / \mathrm{T}($ Yard Tractor, Hereafter $\mathrm{Y} / \mathrm{T})$

\subsection{Study of DEA about environment}

Followings are some insights of DEA research studies which are related with environment and pollutants.

Chung et al. (1997) have estimated efficiency of Swedish paper pulp by using directional distance function, they explained about reduction in undesirable outputs, and introduced radial nature directional distance function. They have shown which kind of relation does directional distance function has with Output Distance Function of Shephared, and proposed that it should be applied as compositional variable in Malmquist type productivity measurement. Also, they asserted that it is more desirable to use Malmquist-Luenberger productivity index in case undesirable output is presented.

Kumar (2006) used nonparametric linear programming to assess directional distance function, and expressed expansion of total factor productivity for 41 countries that were measured by Malmquist-Luenberger index using directional distance function.
Table 2 Summary of Previous Studies about Environment Using DEA

\begin{tabular}{|c|c|c|c|c|}
\hline Researcher & Methodology & $\begin{array}{l}\text { Input } \\
\text { Factor }\end{array}$ & $\begin{array}{l}\text { Output } \\
\text { Factor }\end{array}$ & $\begin{array}{l}\text { Target of } \\
\text { Evaluation }\end{array}$ \\
\hline $\begin{array}{l}\text { Chung et } \\
\text { al. } \\
(1997)\end{array}$ & DDF & $\begin{array}{l}\text { - Labor } \\
\text {-Woody Fiber } \\
\text { - Energy } \\
\text {-Capital }\end{array}$ & $\begin{aligned} \text { y }: \text { Pulp } \\
\text { b : Piochemical } \\
\text { Oxygen } \\
\text { Demand } \\
\text { b : Chemical } \\
\text { Oxygen } \\
\text { Demand } \\
\text { b : Suspended } \\
\text { Solid }\end{aligned}$ & $\begin{array}{l}\text { Pulp and } \\
\text { Paper } \\
\text { Industry } \\
\text { (Sweden) }\end{array}$ \\
\hline $\begin{array}{l}\text { Kumar } \\
(2006)\end{array}$ & DDF & $\begin{array}{l}\text { - Labor } \\
\text { - Capital } \\
\text { - Energy } \\
\text { Consumption }\end{array}$ & $\begin{array}{ll}\mathrm{y} & : \mathrm{GDP} \\
\mathrm{b} & : \mathrm{CO}_{2}\end{array}$ & 41 Countries \\
\hline
\end{tabular}

Footnote : $\mathrm{y}$ is Desirable Output, $\mathrm{b}$ is Undesirable Output

\section{Methodology}

\subsection{Conception of DEA model}

DEA(Data Envelopment Analysis, Hereafter DEA), developed by Charnes et al. (1978), is a mathematical programming approach for analyzing the relative efficiency of peer decision making units(DMUs), which have multiple inputs and multiple outputs.

And DEA is a nonparametric efficiency measurement method, in which first empirical frontier is drawn, and then inefficiency is measured by finding out whether subjects are distanced from efficient frontier.

There are several models in DEA according to use purpose, representative cases are CCR model and BCC model. DEA is further classified into input-oriented and output-oriented.

When the nature of study subject ports is looked into, there needs heavy invest in port development with large scale facilities and it takes long time to construct port. Since cargo handling equipments like $\mathrm{C} / \mathrm{C}$ etc. are highly costly ones, effort should be made to produce maximum output by operating given input variables. Therefore, by assuming that there is a sizable economy is existed in port industry, efficiency was analyzed by using BCC output-oriented model.

\subsection{Conception of Directional Distance Function model}

Generally, Directional Distance Function is separated by Directional Input Distance Function and Directional Output Distance Function, Directional Technology Distance Function. The reciprocal of the distance function is known as the Farrell output measure of technical efficiency (Farrell, 1957). In order to allow for the possibility of crediting firms for the reduction of bad outputs, we use a 
directional output distance function instead of the Shephard output distance function to represent technology. In contrast to the Shephard output distance function which seeks to increase goods and bads simultaneously, the directional distance function seeks to increase the good outputs while simultaneously decreasing the bad outputs (Chung et al., 1997).

There are some restrictions in analyzing with CCR model and BCC model of DEA when undesirable output is considered. Hereby DEA analysis was performed using Directional Technology Distance Function keeping undesirable output in mind in this study.

Directional Technology Distance Function is a new concept distance function including existing distance function when undesirable output such as pollutants $(\mathrm{SO}$, $\mathrm{CO}_{2}$ ) are presented among outputs (Fare and Grosskopf, 1996).

Also, one of the ways that the 'bad' output can be modeled appeared in the pioneered work by Fare et al. (1989) by assuming strong (for desirable outputs) and weak (for undesirable outputs) disposability treating environmental effects as undesirable outputs in a hyperbolic efficiency measure. Generally the property of weak disposability of detrimental variables is well known and has been used in several formulations (Fare et al., 1996; Chung et al., 1997; Tyteca, 1996 \& 1997; Zofio and Prieto, 2001; George and Nickolaos, 2012).

The following equation is weak disposability production frontier model for Directional Distance Function's estimation.

$$
\begin{gathered}
T_{C R S}^{t}=\left(x^{t}, y^{t}, b^{t}\right): \sum_{k} Z_{k} y_{k, m}^{t} \geq y_{m}^{t}, m=1,2, \ldots ., M \\
\sum_{k} Z_{k} b_{k, j}^{t}=b_{j}^{t}, \quad j=1,2, \ldots . ., J \\
\sum_{k} Z_{k} x_{k, n}^{t} \leq x_{n}^{t}, \quad n=1,2, \ldots . ., N \\
Z_{k} \geq 0, \quad k=1,2, \ldots . ., K
\end{gathered}
$$

In the Equation (1), Desirable output(y) and Input factor(x) are having constraints under the condition of strong disposability. And, Undesirable output(b) is having equal sign's constraints under the conditions of strong disposability. Also, $\mathrm{Zk}$ is have constraints greater than zero under the conditions of CRS.

We can identify $\beta$ for the DMU k' using the following linear program familiar from the DEA literature (Fare and
Grosskopf, 2004)

$$
\begin{gathered}
\overrightarrow{D_{T, C R S}^{t}}\left(x^{k^{\prime} t}, y^{k^{\prime} t}, b^{k^{\prime} t},-g_{x}, g_{y},-g_{b}\right)=\max \beta \\
\text { s.t. } \sum_{k} Z_{k} y_{k, m}^{t} \geq y_{k, m}^{t}+\beta g_{y, m}, m=1,2, \ldots . ., M \\
\sum_{k} Z_{k} b_{k, j}^{t}=b_{k, j}^{t}-\beta g_{b, j}, j=1,2, \ldots ., J \\
\sum_{k} Z_{k} x_{k, n}^{t} \leq x_{k, n}^{t}-\beta g_{x, n}, n=1,2, \ldots . ., N \\
Z_{k} \geq 0, k=1,2, \ldots ., K
\end{gathered}
$$

According to study purpose, directional vectors can be set in a variety ways. Directional vector was set as a current input factors and output factors of each DMU in this study. That is, we used Luenberger productivity index which considers directional input distance as well as output distance function at the same time. The linear equation for this estimation is as below Equation (3).

$$
\begin{aligned}
& \overrightarrow{D_{T, C R S}^{t}}\left(x^{k^{\prime} t}, y^{k^{\prime} t}, b^{k^{\prime} t},-g_{x}, g_{y},-g_{b}\right)=\max \beta \\
& \text { s.t. } \sum_{k} Z_{k} y_{k, m}^{t} \geq(1+\beta) y_{k, m}^{t}, m=1,2, \ldots . ., M \\
& \sum_{k} Z_{k} b_{k, j}^{t}=(1-\beta) b_{k, j}^{t}, j=1,2, \ldots . ., J \\
& \sum_{k} Z_{k} x_{k, n}^{t} \leq(1-\beta) x_{k, n}^{t}, n=1,2, \ldots . ., N \\
& Z_{k} \geq 0, k=1,2, \ldots ., K
\end{aligned}
$$

The efficiency index $\beta$ estimated by the above equation is a distance value to approach efficiency. Viz, inefficiency and efficiency value of each DMU is modified as below for analysis.

$$
\lambda=1-\beta
$$

In this case, if efficiency value $\lambda$ becomes nearer to 1 , efficiency can be high, reversely if this value is nearer to 0 , efficiency can be considered as low.

In this study, by using Equation (3) and (4), efficiency values of container terminals were estimated. The program used for the efficiency estimation was LINGO 12.0 and EnPAS. 
Data Envelopment Analysis for Container Terminals Considering an Undesirable Output

- Focus on Busan port \& Kwangyang port

\section{Empirical analysis}

\subsection{Selection of variable}

Efficiencies were estimated subjected to 8 container terminals at Busan port and Kwangyang port during recent 4 years(2007 2010), and analyzed DMU units were Jaseongdae, Sinseondae, Gamman, Uam, and Singamman at Busan port, and Dongbu, KIT, and Korea Express Co. Ltd. at Kwangyang port.

Table 3 Name of DMU for Efficiency Analysis

\begin{tabular}{c|l|l}
\hline \multicolumn{2}{c|}{ DMU } & \multicolumn{2}{c}{ Name } \\
\hline \hline \multirow{4}{*}{$\begin{array}{c}\text { Port of } \\
\text { Busan }\end{array}$} & DMU 1 & Jaseongdae \\
\cline { 2 - 3 } & DMU 2 & Sinseondae \\
\cline { 2 - 3 } & DMU 3 & Gamman \\
\cline { 2 - 3 } & DMU 4 & Uam \\
\cline { 2 - 3 } Port of & DMU 5 & Singamman \\
\hline \multirow{4}{*}{ Kwangyang } & DMU 6 & Dong Bu \\
\cline { 2 - 3 } & DMU 7 & KIT \\
\cline { 2 - 3 } & DMU 8 & Korea Express Co. Ltd. \\
\hline
\end{tabular}

On the basis of existing studies, analysis was carried out by selecting multiple numbers of input variables and output variables. According to the review results of variables related with port efficiency in previous theoretical studies, container throughputs was set as an output variable in most of studies. Though input variables varied depend on the researchers, most of them assigned loading and unloading equipments like port facilities such as number of berth, length of berth, total port area, and cargo handling equipments like number of cranes at quay, number of yard crane etc.

Therefore, quay length, number of $\mathrm{C} / \mathrm{C}$, and $\mathrm{CY}$ area were chosen as input variables, container processing volume was set as a beneficial output, and $\mathrm{CO}_{2}$ emission was set as an undesirable output for efficiency estimation.
Table 4 The Variable of Input and Output

\begin{tabular}{c|c|c|c|c}
\hline \multicolumn{2}{c|}{} & \multicolumn{2}{|c}{ Name of Variable } & Unit \\
\hline \hline \multirow{3}{*}{$\begin{array}{c}\text { Input } \\
\text { Variable }\end{array}$} & $\mathrm{X} 1$ & \multicolumn{2}{|l}{ Length of Quay } & $\mathrm{m}$ \\
\cline { 2 - 5 } & $\mathrm{X} 2$ & \multicolumn{2}{|l|}{ Number of C/C } & number \\
\cline { 2 - 5 } Xutput & $\mathrm{X} 3$ & Area of CY & $\mathrm{m}^{2}$ \\
\hline Variable & $\mathrm{Y}$ & $\begin{array}{c}\text { Desirable } \\
\text { Output }\end{array}$ & $\begin{array}{c}\text { Throughput } \\
\text { of Container }\end{array}$ & TEU \\
\cline { 2 - 5 } & $\mathrm{B}$ & $\begin{array}{c}\text { Undesirable } \\
\text { Output }\end{array}$ & $\begin{array}{c}\mathrm{CO}_{2} \\
\text { Emission }\end{array}$ & tonCO 2 \\
\hline
\end{tabular}

$\mathrm{CO}_{2}$ emission was estimated as per the electricity consumption, and $\mathrm{CO}_{2}$ emission factors per different fuel consumption are as below.

Table 5 CO2 Emission Factor for Each Fuels

\begin{tabular}{c|c|c|c|c|c}
\hline $\begin{array}{c}\text { Fuel } \\
\begin{array}{c}\text { Section } \\
\text { Separation } \\
\left(E_{i}\right)\end{array}\end{array}$ & $\begin{array}{c}\text { Diesel } \\
\left(E_{1}\right)\end{array}$ & $\begin{array}{c}\text { LPG } \\
\left(E_{2}\right)\end{array}$ & LNG $\left(E_{3}\right)$ & $\begin{array}{c}\text { Heavy } \\
\text { Oil } \\
\left(E_{4}\right)\end{array}$ & $\begin{array}{c}\text { Electricity } \\
\left(E_{5}\right)\end{array}$ \\
\hline \hline $\begin{array}{c}\text { Frissions } \\
(\mathrm{kgCO})\end{array}$ & $2.5933 / \mathrm{L}]$ & $\begin{array}{c}\left.3.6078 / \mathrm{Nm}^{3}\right] \\
1.9779 /\left[\mathrm{kg}^{1}\right]\end{array}$ & $\begin{array}{c}2.744 /[\mathrm{kg}] \\
1,960 /\left[\mathrm{Nm}^{3}\right]^{2)}\end{array}$ & $2.9998 / \mathrm{L}]$ & $0.424 /[\mathrm{kWh}]$ \\
\hline
\end{tabular}

Source : KOREA ENERGY MANAGEMENT CORPORATION and KOREA GAS CORPORATION

Footnote : $\mathrm{Ei}$ is $\mathrm{CO}_{2}$ emission factor for each fuels (source : KOREA ENERGY MANAGEMENT CORPORATION)

1) $\mathrm{LPG}[\mathrm{L}]$ 's scaling factor is $1.824[\mathrm{~kg}] /\left[\mathrm{Nm}^{3}\right]$ (Convert into a gaseous state)

2) $\mathrm{LNG}[\mathrm{kg}]\left[\mathrm{Nm}^{3}\right]^{\prime}$ s scaling factor is $714.286[\mathrm{~kg}] /\left[\mathrm{Nm}^{3}\right]$ (source : KOREA GAS CORPORATION)

Descriptive Statistics for the input and output variables shows that average quay length was around 1,171.6m, average number of container crane was around 9.5, average yard area was around $361,000.0 \mathrm{~m}^{2}$, and average container handling volume was around 1,239,783.3TEU, and average $\mathrm{CO}_{2}$ emission was around $5,972.9$ ton $\mathrm{CO}_{2}$.

Table 6 Descriptive Statistic of the Selected Input Variables and Output Variables

\begin{tabular}{c|r|r|r|r|r}
\hline $\begin{array}{c}\text { Input } \\
\text { Output } \\
\text { Variables }\end{array}$ & \multicolumn{1}{|c|}{$\begin{array}{c}\text { Quay } \\
\text { Length }\end{array}$} & $\begin{array}{c}\text { Number of } \\
\mathrm{C} / \mathrm{C}\end{array}$ & Area of $\mathrm{CY}$ & \multicolumn{1}{c}{$\begin{array}{c}\text { Throughput of } \\
\text { Container }\end{array}$} & $\begin{array}{c}\text { Emissions of } \\
\mathrm{CO}_{2}\end{array}$ \\
\hline \hline $\begin{array}{c}\text { Minimum } \\
\text { Value }\end{array}$ & 500.0 & 5.0 & $153,000.0$ & $137,801.0$ & 774.0 \\
\hline $\begin{array}{c}\text { Maximum } \\
\text { Value }\end{array}$ & $1,500.0$ & 15.0 & $672,000.0$ & $2,842,747.0$ & $14,545.0$ \\
\hline Mean & $1,171.6$ & 9.5 & $361,000.0$ & $1,239,783.3$ & $5,972.9$ \\
\hline $\begin{array}{c}\text { Standard } \\
\text { Deviation }\end{array}$ & 333.0 & 4.0 & $173,415.0$ & $898,193.6$ & $4,385.3$ \\
\hline Observations & 32 & 32 & 32 & 32 & 32 \\
\hline
\end{tabular}

Correlation analysis between input and output showed that $90.5 \%$ correlation was found between number of crane and processing result, $85.7 \%$ between number of crane and $\mathrm{CO}_{2}$ emission, high correlation of $94.7 \%$ was found 
between processing result and $\mathrm{CO}_{2}$ emission. This expresses that with increases in container processing volume, many numbers of cargo handling equipments $(\mathrm{C} / \mathrm{C})$ are required, which leads power consumption increased with number of cargo handling equipments involved in operation, which in turn increases $\mathrm{CO}_{2}$ emission.

Table 7 Correlation Analysis of Input Variables and Output Variables

\begin{tabular}{c|l|l|l|l|l}
\hline $\begin{array}{c}\text { Correlation } \\
\text { Analysis }\end{array}$ & $\begin{array}{c}\text { Quay } \\
\text { Length }\end{array}$ & $\begin{array}{c}\text { Number of } \\
\mathrm{C} / \mathrm{C}\end{array}$ & $\begin{array}{c}\text { Area of } \\
\mathrm{CY}\end{array}$ & $\begin{array}{c}\text { Throughput } \\
\text { of Container }\end{array}$ & $\begin{array}{c}\text { Emissions } \\
\text { of } \mathrm{CO}_{2}\end{array}$ \\
\hline Quay Length & 1.000 & $0.771 * *$ & $0.838 * *$ & $0.533 * *$ & $0.532 * *$ \\
\hline $\begin{array}{c}\text { Number of } \\
\mathrm{C} / \mathrm{C}\end{array}$ & $0.771 * *$ & 1.000 & $0.670 * *$ & $0.905 * *$ & $0.857 * *$ \\
\hline Area of CY & $0.838 * *$ & $0.670 * *$ & 1.000 & $0.510 * *$ & $0.543 * *$ \\
\hline $\begin{array}{c}\text { Throughput } \\
\text { of Container }\end{array}$ & $0.533 * *$ & $0.905 * *$ & $0.510 * *$ & 1.000 & $0.947 * *$ \\
\hline $\begin{array}{c}\text { Emissions of } \\
\mathrm{CO} 2\end{array}$ & $0.532 * *$ & $0.857 * *$ & $0.543 * *$ & $0.947 * *$ & 1.000 \\
\hline
\end{tabular}

** : Correlation is significant at the 0.01 level(2-tailed).

\subsection{Analysis of efficiency}

High average efficiency score was found from the result using model with undesirable variables than model that did not consider the undesirable output, and $7(21.8 \%)$ terminals in model with undesirable output and $4(12.5 \%)$ terminals with models without undesirable output were found efficient.

Table 8 Descriptive Statistic of Efficiency Analysis

\begin{tabular}{c|c|c}
\hline Descriptive Statistic & $\begin{array}{c}\text { Reflection Of } \\
\text { Undesirable Output }\end{array}$ & $\begin{array}{c}\text { Reflection Of } \\
\text { Desirable Output }\end{array}$ \\
\hline \hline Maximum Value & 1.000 & 1.000 \\
\hline Minimum Value & 0.247 & 0.148 \\
\hline Mean & 0.880 & 0.687 \\
\hline Standard Deviation & 0.199 & 0.289 \\
\hline $\begin{array}{c}\text { Number Of Terminal } \\
\text { Efficiency }\end{array}$ & $7(21.8 \%)$ & $4(12.5 \%)$ \\
\hline
\end{tabular}

The efficiency analysis result using BCC output-oriented model without considering undesirable output revealed that DMU3 and DMU5 were found as efficient during the year 2007, DMU2 and DMU4 were efficient terminals during the year 2010. DUM6, DMU7 and DMU8 showed relatively very low efficiency during 4 years of investigation period.
Table 9 Result of Efficiency Analysis for Not Considering Undesirable Output (2007 2010)

\begin{tabular}{c|c|c|c|c}
\hline DMUYYear & 2007 & 2008 & 2009 & 2010 \\
\hline \hline DMU 1 & 0.855 & 0.790 & 0.713 & 0.594 \\
\hline DMU 2 & 0.893 & 0.849 & 0.988 & 1.000 \\
\hline DMU 3 & 1.000 & 0.958 & 0.732 & 0.664 \\
\hline DMU 4 & 0.867 & 0.922 & 0.901 & 1.000 \\
\hline DMU 5 & 1.000 & 0.969 & 0.933 & 0.982 \\
\hline DMU 6 & 0.234 & 0.193 & 0.176 & 0.148 \\
\hline DMU 7 & 0.401 & 0.481 & 0.560 & 0.690 \\
\hline DMU 8 & 0.327 & 0.393 & 0.332 & 0.425 \\
\hline
\end{tabular}

While the efficiency analysis result using directional distance function considering undesirable outputs indicated that DMU1 and DMU3 were efficient terminals during the year 2007, and DMU8 was found as relatively low efficient terminal during the same period. During the year 2008, DMU3 and DMU5 were found as efficient terminals, whereas DMU6 was relatively low efficient one. DMU7 is found as efficient terminals during the year 2009, while DMU6 showed relatively very low efficiency. During the year 2010, DMU2 and DMU5 became efficient terminals, while relatively low efficiency was found from DMU6.

Generally, to raise efficiency in DEA analysis, analysis results are being proposed either by reducing input variables or increasing output variables, but there exist many practical restrictions to reduce port facilities, cargo handling equipments, and $\mathrm{CO}_{2}$ emission. Therefore, efficiency has to be increased through improving current input variables.

Table 10 Result of Efficiency Analysis for Considering Undesirable Output (2007 2010)

\begin{tabular}{c|c|c|c|c}
\hline DMU \Year & 2007 & 2008 & 2009 & 2010 \\
\hline \hline DMU 1 & 1.000 & 0.943 & 0.960 & 0.817 \\
\hline DMU 2 & 0.945 & 0.921 & 0.995 & 1.000 \\
\hline DMU 3 & 1.000 & 1.000 & 0.928 & 0.853 \\
\hline DMU 4 & 0.956 & 0.881 & 0.864 & 0.886 \\
\hline DMU 5 & 0.994 & 1.000 & 0.973 & 1.000 \\
\hline DMU 6 & 0.938 & 0.362 & 0.271 & 0.247 \\
\hline DMU 7 & 0.920 & 0.899 & 1.000 & 0.969 \\
\hline DMU 8 & 0.867 & 0.892 & 0.929 & 0.943 \\
\hline
\end{tabular}


Data Envelopment Analysis for Container Terminals Considering an Undesirable Output

- Focus on Busan port \& Kwangyang port

\section{Conclusion}

For the efficiency analysis for container terminal in this study, by using DEA directional production distance function considering undesirable output unlike other port efficiency research, production efficiency was analyzed.

The result of efficiency estimation with directional technology distance function considering undesirable output showed that efficiency value of DMU3(Gamman) became 1 during 2 years i.e., year 2007 and 2008, DMU5(Singamman) showed efficiency value 1 each the year 2008 and 2010. DMU1(Jaseongdae), DMU2(Sinseondae) and DMU7(KIT) showed efficiency value 1 each the year 2007, 2009 and 2010 respectively. The result of efficiency estimation with BCC output-oriented model without considering undesirable output showed efficiency 1 from DMU3(Gamman), DMU5(Singamman) during the year 2007 and efficiency 1 from DMU2(Shinseondae) and DMU4(Uam) during the year 2010. Therefore, efficiency scores with undesirable output were found as higher than those of without undesirable output.

Efficiency estimation results of each container terminal showed large differences depend on the terminal operators. Especially, container terminal at Kwangyang port was concluded to be relatively less efficient than container terminal at Busan port. In Kwangyang port, there are several problems of shortage of service towards LCL cargos, shortage in special containers like refrigeration container, lacking in warehouses, and unbalance in import and export cargo etc., these problem should be improved to increase container processing result. It is clear that large economic loss is unavoidable if container processing result could not be increased by not improving issues in current port facilities scale.

In this study, more accurate efficiency analysis result could not be established by estimating relative efficiency with only $\mathrm{CO}_{2}$ emission by power consumption at container terminals not by considering $\mathrm{CO}_{2}$ emission from vessels, container trucks, and general trucks due to practical disability of data collection etc. Since $60 \%$ of total $\mathrm{CO}_{2}$ emission is attributed by electricity, rest of $40 \%$ is generated by fuel consumption among total $\mathrm{CO}_{2}$ emission at port, it is required to go for efficiency analysis including $\mathrm{CO}_{2}$ emission by fuel consumption also.

\section{References}

[1] Charnes, A., Cooper, W. W. and Rhodes, E.(1978), "Measuring the Efficiency of Decision Making Units", European Journal of Operational Research, Vol. 2, No. 6, pp. $429-444$.

[2] Cho, D. O.(2010), "A Comparative Study On Low-Carbon Port Management of Busan and LA/LB: On the Basis of Port Management Cost", Journal of Korean Society of Marine Environment \& Safety, Vol. 16, No. 2, pp. 223-228.

[3] Choi, B. H., Shin, J. Y., Yang, Y. O. and Shin, C. H.(2009), "Efficiency Measurement Of Container Terminals with DEA Using an Input Variable of Information Level", Journal of Korean Navigation and Port Research, Vol. 33, No. 8, pp. 573-581.

[4] Chung, Y. H., Fare, R. and Grosskopf, S.(1997), "Productivity and Undesirable Output: A Directional Distance Function Approach", Journal of Environmental Management, Vol. 51, pp. 229-240.

[5] Cullinane, K., Song, D. W. and Gray, R.(2002), "A Stochastic Frontier Model of The Efficiency of Major Container Terminals in Asia: Assessing the Influence of Administrative and Ownership Structure", Transport Research Part A, pp. 743-762.

[6] Fare, R., Grosskopf, S., Lovell, C. A. K. and Pasurka, C.(1989), "Multilateral Productivity Comparisons When Some Outputs are Undesirable", The Review Economic Statistics, Vol. 71, pp. 90-98.

[7] Fare, R. and Grosskopf, S.(1996), "Intertemporal Production Frontiers: With Dynamic DEA", Boston Kluwer Academic Publishers

[8] Fare, R. and Grosskopf, S.(2004), "Modeling Undesirable Factors in Efficiency Evaluation: Comment", European Journal of Operational Research, Vol. 157, pp. $242-245$.

[9] Fare, R., Grosskopf, S. and Tyteca, D.(1996), "An Activity Analysis Model of the Environment Performance of Firms: Application to Fossil-Fuel-Fired Electric Utilities", Journal of Ecology Economics, Vol. 18, pp. 161-175.

[10] Farrell, M. J.(1957), "The Measurement of Productive Efficiency", Journal of the Royal Statistical Society, Vol. 120, pp. 253-281.

[11] George, E. H. and Nickolaos, G. T.(2012), "Measuring German Regions' Environmental Efficiency: A Directional Distance Function Approach", Letters in 
Spatial and Resource Sciences, Vol. 5, pp. 7-16.

[12] Jeong, B. H.(2009), "Green Port Management Policy Directions in the Green Growth Era-The Case of Gwangyang Port in Republic of Korea", Journal of Korea Port Economic Association, Vol. 25, No. 3, pp. 361-384.

[13] Kumar, S.(2006), "Environmentally Sensitive Productivity Growth: A Global Analysis Using Malmquist-Luenberger Index", Ecological Economic, Vol. 56, pp. 280-293.

[14] Mo, S. W. and Lee, K. B.(2010), "The Efficiency of Container Terminals in Busan and Gwangyang Port", Journal of Korea Port Economic Association, Vol. 26, No. 2, pp. 139-149.

[15] Park, H. G.(2010), "The Data Envelopment Analysis of Container Terminals to Transshipment Cargo", Journal of Korea Port Economic Association, Vol. 26, No. 1, pp. 1-19.

[16] Park, R. K. and Lee, B. H.(2007), "A Measurement Way Comparison on the Container Terminal Efficiency Using Radial and Non-Radial DEA Approach", The Journal of Shipping and Logistics, Vol. 53, pp. 17-41.

[17] Roll, Y. and Hayuth Y.(1993), "Port Performance Comparison Applying Data Envelopment Analysis(DEA)", Maritime Policy and Management, Vol. 20, No. 2, pp. 153-161.

[18] Tyteca, D.(1996), "On the Measurement of the Environmental Performance of Firms: A Literature Review and a Productive Efficiency Perspective", Journal of Environmental Management, Vol. 46, pp. 281-308.

[19] Tyteca, D.(1997), "Linear Programming Models for the Measurement of Environmental Performance of Firms: Concepts and Empirical Results", Journal of Productivity Analysis, Vol. 8, pp. 175-189.

[20] Zofio, J. L. and Prieto, A. M.(2001), "Environmental Efficiency and Regulatory Standards: The Case of $\mathrm{CO} 2$ Emissions From OECD Industries", Resource and Energy Economics, Vol. 23, pp. 63-83.

Received 28 February 2013

Revised 22 March 2013

Accepted 25 March 2013 